\title{
Online Veterinary Anatomy Education in the Era of COVID-19 Pandemic: Pros and Cons
}

\author{
Educación en Línea de Anatomía Veterinaria en la Era \\ de la Pandemia de COVID-19: Ventajas y Desventajas
}

Om Prakash Choudhary

CHOUDHARY, O. P. Online Veterinary Anatomy Education in the era of COVID-19 Pandemic: Pros and Cons. Int. J. Morphol., 39(4):1231-1233, 2021.

SUMMARY: Consecutive waves of the COVID-19 pandemic made teaching and learning tasks harder for veterinary anatomy faculties and students worldwide compared to the prepandemic scenario. Online teaching has been triggered across several countries as a precautionary measure against COVID-19. Educational institutions are looking towards online learning platforms to continue educating the students, as many veterinary institutes have been shut down due to COVID-19. As with most teaching methods, online learning also has its own set of positives and negatives. This letter aims to highlight the pros and cons of online veterinary anatomy education in the COVID-19 pandemic period. In conclusion, prepandemic teaching has been effective and adaptable for veterinary anatomy students for a better learning process, whereas online teaching has major cons over a few pros.

KEY WORDS: SARS-CoV-2, COVID-19; Veterinary anatomy; Online; Teaching.

Dear Editor:

As day-to-day life, including education, has come to a standstill amid the COVID-19 pandemic, online teaching has been adopted by educational institutes worldwide. In virtual methods for teaching veterinary anatomy, some pros and cons have been described in detail in this article. In a previous study, the pros and cons of the online teaching program in medical anatomy have been elaborated (Choudhary, 2021; John et al., 2021). However, there is no discussion on the advantages and disadvantages of online veterinary anatomy education till date; hence being a faculty member teaching veterinary anatomy to the budding veterinarians, I have drafted this Letter to the Editor to highlights this current issue in the period of the COVID-19 pandemic.

\section{PROS}

Contactless: SARS-CoV-2, the causative agent of COVID19 , is mainly transmitted by three primary modes i.e. aerosol, droplet, and contact transmission (Priyanka et al., 2020; Al-Dorazi \& Al-Talalwah, 2021). Hence, while taking classes using Zoom and Google Meet platforms, there is zero-contact teaching, which would mitigate the spread of this infectious agent amongst the veterinary anatomy teachers and students.
Efficiency: In the virtual world of veterinary anatomy, there are several online platforms to teach the students for the enhanced learning process, such as PDFs, videos, podcasts, and teachers can use all these tools as part of their lesson plans (Gautam, 2020). By extending the lesson plan beyond traditional textbooks to include online resources, teachers can become more efficient educators (Gautam). Several website links can be shared with students to have an interactive approach in learning veterinary anatomy.

Accessibility: Another advantage of online education is that it allows students to attend classes from any place of the student's choice. Additionally, online class lectures can be recorded, archived, and shared for student's future reference. This feasibility allows students to access the learning material at a time of their comfort. Thus, online veterinary anatomy education offers students the accessibility of time and place in education.

Student attendance: Since online classes can be taken from home or location of choice, there are fewer chances of students missing out on the interesting topics covering the various aspects of veterinary anatomy. 
Variety of learning styles: Every student has a different learning journey and a different learning style. Some students are visual learners, while some students prefer to learn through audio. Similarly, some students thrive in the classroom, and other students are solo learners who get distracted by large groups (Gautam). With its range of options and resources, the online learning system can be personalized in many ways. It is the best way to create a perfect learning environment suited to the needs of each student.

\section{CONS}

Technology issues: Internet connectivity issues are the major cons of online veterinary teaching. Without a consistent internet connection for students or teachers, there can be a lack of continuity in learning for the child (Gautam). This is detrimental to the education process among veterinary anatomy students.

Economic restraint: Not all veterinary anatomy students are financially sound to acquire the requirements for online learning. In our college, some of the students are not financially sound, which is an obstacle for the students to procure items needed for online classes such as laptops and internet devices.

Inability to focus on screens: For many veterinarian students, one of the biggest challenges of online learning is focusing on the screen for long periods. With online teaching and learning methodology, there is also a greater chance for students to be easily distracted by social media or other sites. Therefore, the teachers must keep their online classes crisp, engaging, and interactive to help students stay focused on the lesson.

Hands-on-practicals: The online platforms are not suitable for the veterinary anatomy students for teaching as there is a compromise on the hands-on practical knowledge. For example, various dissection methods give students a three-dimensional image of animal anatomy, corroborate and give details about the information gained by lectures. Despite the advances in technology, cadaveric dissection is believed to be the ideal and most effective method of teaching anatomy (Ghosh, 2017). It has been mentioned earlier that when students lost access to dissection rooms, they lost access to cadavers and a range of other optimal learning modalities: prosections, models, pathology specimens, skeletons, and others (Sugand et al., 2010).

Group discussion: As there are no physical interactions between students and teachers in online teaching, group discussions are not feasible. This often results in a sense of isolation for the students. In this situation, it is imperative that other forms of communication are complemented between the students, peers, and teachers. These can include online messages, emails, and video conferencing, which would allow face-to-face interaction and reduce the sense of isolation.

Student attitude: The classroom environment is not provided to the students; hence we are not able to track the interest of the students in the online teaching, whether they are good listeners or avoiding the lectures by keeping phone or laptop aside. This attitude not only harms the student while learning veterinary anatomy but also hampers the clinical and applied aspect of the veterinary anatomy during various hands-on practices in their future endeavors.

In conclusion, there are several pros and cons of online veterinary anatomy education.

However, unlike the two equivalent sides of a coin, the cons far outweigh the pros as the future and knowledge of budding veterinarians lie at stake. From my perspective, I am eagerly waiting for the end of this COVID-19 pandemic and entering the teaching methodology used in the prepandemic period.

CHOUDHARY, O.P. Educación en línea de anatomía veterinaria en la era de la pandemia de COVID-19: Ventajas y desventajas. Int. J. Morphol., 39(4):1231-1233, 2021.

RESUMEN: Las oleadas consecutivas de la pandemia COVID-19 han dificultado las tareas de enseñanza y aprendizaje para las facultades de anatomía veterinaria y para los estudiantes de todo el mundo en comparación con el escenario prepandémico. Se ha activado en varios países la enseñanza en línea como medida de precaución durante la crisis de la COVID-19. Las instituciones educacionales están buscando plataformas de aprendizaje en línea para continuar la enseñanza de los alumnos, debido a que muchos institutos veterinarios se han cerrado. Como ocurre con la mayoría de los métodos de enseñanza, el aprendizaje en línea también tiene su propio conjunto de aspectos positivos y negativos. Este estudio tiene como objetivo resaltar las ventajas y desventajas de la educación en anatomía veterinaria en línea en el período de la pandemia de la COVID-19. En conclusión, la enseñanza prepandemia ha sido eficaz y adaptable para los estudiantes de anatomía veterinaria para lograr un proceso mejor de aprendizaje, mientras que la enseñanza en línea tiene mayores desventajas.

PALABRAS CLAVE: SARS-CoV-2; COVID-19; Anatomía veterinaria; Online; Docencia. 


\section{REFERENCES}

Al-Dorazi, S. \& Al-Talalwah, W. New clinical anatomical interpretation of COVID-19 pandemic infection. Int. J. Morphol., 39(2):635-7, 2021

Choudhary, O. P. Consequences of the COVID-19 pandemic on veterinary anatomy education in India. Int. J. Morphol., 39(2):623-4, 2021.

Gautam, P. Advantages and Disadvantages of Online Learning. eLearning Industry, 2020. Available from: https://elearningindustry.com/ advantages-and-disadvantages-online-learning

Ghosh, S. K. Cadaveric dissection as an educational tool for anatomical sciences in the 21st century. Anat. Sci. Educ., 10(3):286-99, 2017.

John, M. R.; Sharma, D. K.; Poonuraparampil, J. A. \& Konuri, V. K. A study on the advantages and disadvantages of the online teaching program conducted in the Department of Anatomy, AIIMS, Raipur students' perspective. Natl. J. Clin. Anat., 10(1):10-6, 2021.

Priyanka; Choudhary, O. P.; Singh, I. \& Patra, G. Aerosol transmission of SARS-CoV-2: The unresolved paradox. Travel Med. Infect. Dis., $37: 101869,2020$

Sugand, K; Abrahams, P. \& Khurana, A. The anatomy of anatomy: a review for its modernization. Anat. Sci. Educ., 3(2):83-93, 2010.
Corresponding author:

Dr. Om Prakash Choudhary

Department of Veterinary Anatomy and Histology

College of Veterinary Sciences and Animal Husbandry

Central Agricultural University (I)

Selesih, Aizawl-796 015

Mizoram

INDIA

E-mail: dr.om.choudhary@gmail.com

ORCID: Om Prakash Choudhary 0000-0001-6929-675X

Received: 26-04-2021

Accepted: 02-06-2021 